\title{
Adoption of IFRS for SMEs in Albania
}

\author{
Albana Gjoni ${ }^{1}$, Shpresa Çela ${ }^{1}$, Drini Salko ${ }^{1} \&$ Migena Qerimi ${ }^{1}$ \\ ${ }^{1}$ Agricultural University of Tirana, Tirana, Albania \\ Correspondence: Albana Gjoni (Karameta), Agricultural University of Tirana, Tirana, Albania. E-mail: \\ agjoni@ubt.edu.al
}

Received: October 5, 2020

Accepted: December 21, 2020

Online Published: January 20, 2021

doi:10.5430/rwe.v12n2p158

URL: https://doi.org/10.5430/rwe.v12n2p158

\begin{abstract}
Small Medium-Sized Enterprises (SMEs) is one of the most important engines of economic growth in Albania. They make a significant contribution to local and global trade and also to the national economic development. SMEs have the largest proportion of total Albanian employment, almost 78\% of the total number of employed people. They generally face difficulties in financing and investing decisions, globalization, and other matters, mainly because of their inappropriate formal financial reports. These enterprises must prepare adequate financial statements and proper accounts to deal with third parties' needs and ensure stakeholder's confidence. This requires financial statements to be prepared by international financial reporting standards (IFRS), national accounting standards, and local government laws. Therefore, the International Accounting Standards Board (IASB) provided a new standard to ensure the required financial reporting quality for SMEs. The main focus of this study is to examine the attitudes of financial statement's information' users in Albania towards the adoption of this financial reporting standard for SMEs as progress on the general financial reporting process in Albania, and also to estimate their capabilities and interests on this matter.
\end{abstract}

Keywords: SMEs, national accounting standards, international financial reporting standards, financial statements, financial reporting, EU accounting directive

\section{Problem of Study}

Small Medium-Sized Enterprises all over the world are required to prepare financial statements in accordance with the financial reporting framework approved by their legal local authorities. There has been a lengthy discussion regarding the development of unique standards set for all SMEs regardless of their business size. These discussions led the IASB on making a decision for issuing an international accounting standard for all SMEs (Pacter, p.31). Accordingly, from July 2003 IASB officially started the project of preparing and issuing a specific financial reporting standard for SMEs. In October 2009, IASB published the official IFRS for SMEs (IASB, 2009), and its most recent updates can be found in publications of the year 2018 (IASB 2018). In accordance with SMEs' importance to Albanian economic development, the National Accounting Committee in cooperation with World Bank that supported financially the accounting reforms in the early 2000s and in collaboration with Price Water House Coopers started the preparation of national accounting standards set. In the beginning, they used just a simplified version of the IFRS and IAS adapted to Albanian enterprise's needs. The improved law on Accounting and Financial Statements was published and approved in 2004, but the obligation for publication of the financial statements was lately formally approved in 2008. This law categorized all enterprises referring to the employers' number and yearly turnover. In order to facilitate the application of accounting official rules, the accounting national committee in collaboration with the ministry of finance and other related third parties provided 15 new national accounting standards for all Albanian enterprises. The new accounting standard 15 was published a year later, referring to specifically Albanian SMEs' needs for accounting and financial reporting issues. Its latest updates came out in 2019. The latest improvements were made in 2018 referring to Law on "Accounting and Financial Statements", recommending adoption of IFRS in accordance with EU financial agencies' policies. The main research question is the decision of whether to improve and adjust current national accounting standards or to adopt the new IFRS for SMEs commonly used in EU countries. A second research question, is the adoption of IFRS for SMEs an added value to financial reporting in Albania? 


\subsection{Objective of the Study}

The Main objective of the study is to investigate whether the adoption of IFRS for SMEs adds value to the financial reporting process in Albania. In terms of financial reporting and analysis, this study aims to consider financial statement users' perception of this standard and consider it useful in terms of preparing financial statements and reporting relevant information.

\section{Research Literature}

Table 1. Research literature

\begin{tabular}{ll}
\hline \multicolumn{1}{c}{ Authors } & \multicolumn{1}{c}{ Literature Review } \\
\hline Neag, Masca \& Pascan, & 1. Adopting IFRS for SMEs will improve the quality and comparability of financial \\
re09 & reporting information for SMEs, will improve the reliability and comparability of \\
& financial information in terms of globalization. Improved financial statements by more \\
& comparable and reliable financial information will give better access to SMEs on \\
& financial resources. \\
& 2. According to this theory, the main users of financial statement information are banks, \\
& sellers, credit agencies, different lenders, venture capitalists, investors, owners, tax \\
authorities, and government agencies.
\end{tabular}

Sinnett and Mesa Adoption of IFRS for SMEs, bringing a higher information quality could improve the Graziano, 2006 companies financing situation.

Pacter, 2004

1. If every enterprise in different countries prepares financial statements in accordance with local standards, comparability is reduced globally because different regulation means different accounting and reporting practices, less comparability, and harmonization.

2. Same as point 2 of author Neag, Masca \& Pascan, 2009

IASC Foundation 1. Same as point 2 of author Neag, Masca \& Pascan, 2009

Education, 2009

2. SMEs' Financial Statement users are mainly interested in general financial information about SMEs and have no specific requirements for this information.

3. Different accounting standards reduce the comparability and understandability of financial information for all financial information users.

3. Potential Benefits that arise from the adoption of IFRS for SMEs cannot be limited to lenders and investors' benefits, also other third related parties such as companies searching for financial capital from financial markets can benefit from the adoption of IFRS for SMEs, by reducing the cost of uncertainty and harmonization, and therefore reducing the cost of capital.

4. From a benefits point of view, the theory suggests that financial reports generated in accordance with IFRS for SMEs could have higher quality. 5. Many SMEs are in need of bank loans and in terms of achieving it, banks need financial statements with higher information quality in order to fix specific loan terms.

Mirza, Holt \& Orrell, 1. Theory suggests that the adoption of IFRS for SMEs aims to increase the quality of 2008 information, harmonization, and comparability for all different users. Implementation of IFRS for SMEs can increase market efficiency and reduce the cost of capital.

2. Theory suggests that IFRS for SMEs was developed to address the reporting needs of accounting principles such as going on concern principle and accuracy principle. These accounting principles can be determined as the true basis of reliable information in terms of financial statement preparation.

Lippitt \& Oliver, 1983 1. Same as point 2 of author Neag, Masca \& Pascan, 2009

2. SMEs' financial statement users are different from large enterprises users because they have different needs and requirements.

3. Return on Equity is important to SMEs and large enterprises because their investing 
and financing decisions are related to the cost of capital.

4. Theory suggests that owners (managers or not) of SMEs are more active in managing activities because they are deeply involved, have better access to internal information compared to large enterprises. This close relation to management makes owners depend less on financial reports in terms of business decision making.

Epstein

Jermakowicz, 2010

\& 1. Financial statement users are interested to financial position information, financial performance information, and information about the changes in financial position in terms of financial analysis and decision-making process.

2. To attract capital investors' attention an enterprise should prepare financial statements in accordance with IFRS for SMEs, in order to offer proper financial information referring to the financial position and financial performance.

1. Cost of capital will be lower as a result of a positive attitude of European investors of European enterprises toward the adoption of IFRS for SMEs, therefore providing a higher quality of financial reporting. Armstrong, Barth,
Jagolinzer \& 2008

Jarvis, 2003

Aras \& Croether, 2008

Street and Jr. Needles, 2009

Taylor, 2009

Harvey \& Walton, 1996

Shortridge \& Myring, 2004

Lungu, Caraiani, \& 1. Theory suggests that tax authorities are the biggest users of financial statement's information for SMEs. These authorities use the information to calculate gross profit, 
Dascalu, 2007

IASB, 2009

Hoxha E, 2014

Kılıç M. and Uyar A. 2017

Ballas. A, Skoutela, D. \& Tzovas, C.A. (2010) managers' bonuses, tax rates, total expenses and to control that expenses are correct to be recorded.

Different countries have different low and tax regulations, and financial statements could not be prepared in total accordance with IFRS for SMEs. In this situation, SMEs will prepare two sets of financial statements, one in accordance with IFRS for SMEs and one in accordance with local tax low. Changes in tax law can be made only by government authorities when it is in accordance with the public interest.

There are a few important differences between the National Accounting Standards and the IFRS for SMEs, and it would be easier if we could integrate only those parts of this new standard that make important difference, with the current National Accounting Standard in Albania, and this process minimises costs and time for training of financial statement preparers.

Some challenges and obstacles may be encountered by entities in the first application of the IFRS for SMEs and during the adoption process as a lack of trained personnel, interpretation difficulties, and language issue. Our research indicated that one of the most important challenges facing the SMEs for the adoption process of IFRS for SMEs was the lack of trained personnel. Supporting this finding, prior research showed that there was a lack of preparation among accountant professionals and SMEs

Concerns about the application and adaptation costs are also considered to be important challenges for the IFRS for SMEs adoption process. Although the adoption of the IFRS for SMEs is less costly compared with the adoption of the full set of IFRS, adoption costs remain the main disadvantage because certain fixed conversion or implementation costs will be burdensome for small entities (Ballas et al., 2010).

The relevant research literature that has been published on this topic offers a very large quantity of information to weigh the pros and cons about the adoption or not of the new IFRS for SMEs in Albania and other different countries, but still, there has not been offered any research instrument by Albanian researchers to generate a final conclusion on whether to adopt the new standard or just improve the existing one. The pros theories are based on the overall financial reporting progress and easier integration of the country in the EU. The cons theories are based on the discussions about higher implementing costs, timing costs and uncertainty costs. This study aims to answer to the research question whether to adopt a new standard on financial reporting for SMEs or to improve the existing one.

\section{Method}

Empirical data were collected to conduct this study; they have been analyzed using quantitative and qualitative methods. The qualitative research method was used to address the financial statement users' opinions and the quantitative research method to measure and analyze different variables and test hypotheses of the study. A survey questionnaire was used to collect primary data for this study; the sample consisted of 120 financial statement users, all of them daily users of financial reporting information. Qualitative research data was collected through interviews with financial statement preparers, 60 preparers.

\subsection{Hypothesis of the Study}

Hypothesis 1: Financial Statement users are ready to adopt IFRS for SMEs.

Hypothesis 2: Financial Statement users have a positive attitude toward the adoption of IFRS for SMEs as an added value to the financial reporting process in Albania.

Hypothesis 3: Benefits deriving from the adoption of IFRS for SMEs has a positive impact on financial statements users.

Hypothesis 4: Reporting frequencies and financial reporting information update affect financial statement users' attitudes toward adopting IFRS for SMEs.

In order to design a research method for this study we chose a research survey because the local national accounting standard has been revised lately in 2019, and yet the financial information users and financial statement preparers are facing problems of familiarity with this local national standard, therefore is still hard to collect significant data for the adoption of a new standard which could generate new costs of implementation or training, timing costs, and also uncertainty costs. 


\section{Results}

Survey and interview methods were used for this study. The survey questionnaire was directed to financial statement users, 120 users, all of them daily expert users. The financial statement preparers were objected to an interview, specifically 60 interviews. Data collected to test the hypotheses of the study were analyzed using the statistical methods. The financial statement users' attitudes toward adoption of IFRS for SMEs is considered as the dependent variable, influenced by different independent variables like interest group representing financial statement users, the gender of users, age of users, objectives of financial reporting, benefits from the adoption of IFRS for SMEs, frequency, and update of financial reporting, etc.

We developed correlation and linear regression earlier as a way of expressing the strength and linear relationship between variables :

$Y_{i}$ - Dependant Variable

$$
Y_{i}=\beta_{0}+\beta_{1} X_{i}+\varepsilon_{i}
$$

$\beta_{0}$ - Population Intercept

$\beta_{1}$ - Population Slope Coefficient

$X_{i}$ - Independent Variable

$\varepsilon_{i}$ - Random Error component

Below are listed the results for the hypothesis:

Table 2. Results of the study

\begin{tabular}{|c|c|c|c|}
\hline Hypothesis & $\begin{array}{l}\text { Significance } \\
\text { variables }\end{array}$ & $\begin{array}{l}\text { Correlation } \\
\text { Coefficient } R\end{array}$ & R square \\
\hline Hypothesis 1: & $\begin{array}{l}\text { Significance }=.000 \text { coef. } \\
\text { p-value }<\alpha=0.05, \mathrm{H} 0 \text { is } \\
\text { rejected in favor of } \mathrm{H} 1\end{array}$ & $\begin{array}{l}\mathrm{R}=.868 \text {, there is a } \\
\text { positive } \\
\text { relationship. }\end{array}$ & $\begin{array}{l}\text { R Square }=.754 \\
75.4 \% \text { of financial statements users' attitudes for } \\
\text { SMEs are influenced by the interest group of users. } \\
\text { This value shows that the relationship is strong and } \\
\text { significant. }\end{array}$ \\
\hline Hypothesis 2: & $\begin{array}{l}\text { Significance }=.000 \text { coef. } \\
\text { p-value }<\alpha=0.05, \mathrm{H} 0 \text { is } \\
\text { rejected in favor of } \mathrm{H} 1\end{array}$ & $\begin{array}{l}\mathrm{R}=.754 \text {, there is a } \\
\text { positive } \\
\text { relationship. }\end{array}$ & $\begin{array}{l}\text { R Square }=.568 \\
56.8 \% \text { of financial statements users' attitudes for } \\
\text { SMEs are influenced by the objectives of users in } \\
\text { terms of financial reporting objectives. This value } \\
\text { shows that the relationship is significant. }\end{array}$ \\
\hline Hypothesis 3: & $\begin{array}{l}\text { Significance }=.000 \text { coef. } \\
\text { p-value }<\alpha=0.05, \mathrm{H} 0 \text { is } \\
\text { rejected in favor of } \mathrm{H} 1\end{array}$ & $\begin{array}{l}\mathrm{R}=.893 \text {, there is a } \\
\text { positive } \\
\text { relationship. }\end{array}$ & $\begin{array}{l}\text { R Square }=.798 \\
79.8 \% \text { of financial statements users' attitudes for } \\
\text { SMEs are influenced by the benefits of users from } \\
\text { adoption of IFRS for SMEs. This value shows that } \\
\text { the relationship is strong and significant. }\end{array}$ \\
\hline Hypothesis 4: & $\begin{array}{l}\text { Significance }=.000 \text { coef. } \\
\text { p-value }<\alpha=0.05, \mathrm{H} 0 \text { is } \\
\text { rejected in favor of H1 }\end{array}$ & $\begin{array}{l}\mathrm{R}=.848 \text {, there is a } \\
\text { positive } \\
\text { relationship. }\end{array}$ & $\begin{array}{l}\text { R Square }=.718 \\
71.8 \% \text { of financial statements users' attitudes for } \\
\text { SMEs are influenced by the frequency and updates of } \\
\text { financial reporting information. This value shows that } \\
\text { the relationship is strong and significant. }\end{array}$ \\
\hline
\end{tabular}

This study aimed to investigate financial statement users' attitudes in Albania toward the adoption of IFRS for SMEs. Conclusions will be drawn in accordance with the hypotheses of the study and research questions determined just from the beginning. Below are some conclusions from the empirical study:

1. Financial statement users' attitudes toward adoption of IFRS for SMEs - Interest Group representing users of financial statements 
Financial Statements users represented different interest groups like Investment companies, Credit institutions, the Institute of Statistics, Business partners, Tax authorities, Government authorities, etc. These users can be categorized into two types, those who support the adoption of IFRS for SMEs and those who don't support the adoption process.

2. Financial statement users' attitudes toward adoption of IFRS for SMEs - Objectives of Financial reporting

There are many financial reporting objectives such as regulation standardization, surveillance of industry financial information, investment and financing decisions, foreign investment objectives, monitoring contract fulfillment, data collection, and analysis, etc. According to these specific objectives, users of financial statements for SMEs change their attitudes toward the adoption of IFRS for SMEs.

3. Financial statement users' attitudes toward the adoption of IFRS for SMEs - Benefits of financial statements users from the adoption of IFRS for SMEs

Financial statement users' attitudes toward the adoption of IFRS for SMEs are affected by benefits that users generate from the adoption of IFRS for SMEs. There are many benefits that can be generated from the adoption of IFRS for SMEs such as improved transparency, improved information financing, and investment decisions, improved financial stability, improved financial control, less fiscal evasion, better statistical data, etc. All these benefits stimulate users of financial statements to consider the adoption of IFRS for SMEs as an added value to the financial reporting process in Albania.

4. Financial statement users' attitudes toward the adoption of IFRS for SMEs - Reporting frequency and update of financial reporting information

Monthly update of financial reporting information, or half-year update, or 3-month update through enterprise official website, via email or other official ways like publications through national registration center web, has affected financial statements users' attitudes toward the adoption of IFRS for SMEs. Technology innovation has facilitated the use of financial reporting information for users through quick and easy access.

In conclusion, empirical research results have shown that the adoption of IFRS for SMEs adds value to the financial reporting process in Albania.

The qualitative research study was developed through an interview directed to financial statement preparers. Results of this study are listed in accordance with three main research questions:

\section{Political point of view}

From a political point of view, preparers of financial statements and users were asked different questions, in order to estimate the added value from the adoption of IFRS for SMEs; some important questions are listed below:

a) Is the adoption of IFRS for SMEs a pre-condition for the EU integration of Albania?

Results of the research show that actually, adoption of IFRS for SMEs is not part of the EU agenda of integration of Albania. EU for the moment asks an approach to the EU directive for accounting, but not mandatory with IFRS and IAS. Most parts of the interviewees think there is no pre-condition for the EU integration of the country, actually $46.4 \%$ of them. They think the adoption of the local national accounting standards should be made in an approach with the EU accounting directive.

b) Is the adoption of IFRS for SMEs an incentive to foreign investments in Albania?

According to the research results of the study, there is no confirmation of the theory referring to the correlation between the quality of financial reporting and foreign investment incentives. From 2008, National Accounting Standards offer to foreign investors the opportunity to compare financial information generated from financial statements. This conclusion suggests that the adoption of IFRS for SMEs is not a key to foreign investment success in Albania.

\section{Technical point of view}

a) Is there an essential difference between the EU accounting directive and IFRS for SMEs to prevent the adoption of IFRS for SMEs?

This question is really important because our country as a candidate for EU membership has a priority to the EU directive approach if compared to IFRS adoption. EU accounting directive is the guide to all EU member countries and those countries aspiring to become EU members. On the other hand, IFRS for SMEs and National Accounting Standards are both in accordance with this directive and none of them has an essential difference with the directive itself. To this context, the adoption of IFRS for SMEs is progressing to harmonization with the EU accounting 
directive.

b) Is there any essential difference between National Accounting Standards and IFRS for SMEs in order to ask for structural basic changes in the conceptual framework of financial reporting or any improvements that should be done?

There are differences between National Accounting Standards and IFRS for SMEs, but these differences are not essential such as changing the whole financial regulation in Albania. Adoption can be realized for specific sections that are not applied in Albania currently. Although adoption can be made to improve current accounting and financial reporting practices. From this point of view, the adoption of IFRS for SMEs can add value to the financial reporting process only partially.

c) Is there a positive and measurable relationship between the adoption of IFRS for SMEs and the quality of economic decisions for financial statement users and preparers?

The results of the research show that only $42 \%$ of the sample thinks that the adoption can improve essentially the financial reporting process, $44.9 \%$ of them think the adoption can improve partially the financial reporting process.

\section{Economic point of view}

a) Are the owners of these enterprises ready to invest in the qualification and training of professional staff for the purpose of adoption of IFRS for SMEs?

The results of the study show that $55.1 \%$ of the interviewees are ready to invest in further professional staff qualifications in terms of the adoption of IFRS for SMEs. The other part of the interviewees is skeptical or totally disagrees with this process. Accordingly, not only owners but also different users face problems of higher costs arising from adoption. The government should update its budgets to the new changes, professional committees and institutions should forecast future training, etc. In addition, university curricula should be updated to these new changes, causing new arising costs from this adoption process.

\section{Conclusions}

Descriptive and empirical research data show that the adoption of IFRS for SMEs is an added value to the financial reporting process in Albania, but in some aspects the effects are partial. We think that only those sections that have a positive impact on financial reporting and that are also appropriate from the Albanian SMEs practice should be adopted, as there are many sections of IFRS for SMEs that do not fit the local business practice. The results of the study show that there are differences between IFRS and National Accounting Standards (NAS) in Albania, but not essential to change the entire financial national regime. A further improvement to the Albanian NAS is necessary to approach the important IFRS sessions missing. The results of the study also show that both IFRS and Albanian NAS are way apart from the EU Directive, and this means that the IFRS adoption is not a further step to EU integration of the country. The results of the study show that the adoption of IFRS for SMEs has not a measurable positive impact on foreign investments in Albania. On the other hand, increased reporting frequency and financial reporting information update improve IFRS for SMEs' attitude toward IFRS adoption. Determination of users' financial reporting objectives has also a positive effect on IFRS for SMEs' users' attitudes toward IFRS adoption. Interest groups vary a lot on their attitude toward IFRS for SMEs adoption. Financial institutions have to face higher costs of training and implementation and are skeptical to this purpose, government agencies have to face planning difficulties, but there are many other users such as investors or stockholders who agree to the adoption in order to approach better regulation and achieve improved financial reporting information. In order to design a research method for this study we chose a research survey because the local national accounting standard has been revised lately in 2019, and yet the financial information users and financial statement preparers are facing problems of familiarity with this local national standard, therefore is still hard to collect significant data for the adoption of a new standard which could generate new costs of implementation or training, timing costs, and also uncertainty costs. But we intend to continue the research on this topic because it is really important for the public interest in Albania.

\section{References}

Aras, G., \& Crowther, D. (2008). Developing sustainable reporting standards. Journal of Applied Accounting Research, 9(1), 4-16.

Armstrong, C. S., Barth, M. E., Jagolinzer, A. D., \& Riedl, E. J. (2008). Market Reaction to the Adoption of IFRS in Europe. Harvard Business School Working Papers. Retrieved from http://www.hbs.edu/research/pdf/09-032.pdf

Ballas, A., Skoutela, D., \& Tzovas, C. A. (2010). The relevance of IFRS to an emerging market: Evidence from Greece. Managerial Finance, 36(11), 931-948. 
Epstein, B. J., \& Jermakowicz, E. K. (2010). Wiley IFRS 2010: Interpretation and Application of International Accounting and Financial Reporting Standards 2010. New Jersey: John Wiley \& Sons, Inc.

Harvey, D., \& Walton, P. (1996). Differential Reporting - An Analysis (NVM Foundation). London: The Foundation for Manufacturing and Industry.

Hoxha, E. (2014). Is the Adoption of IFRS for SMEs an Added Value for the Financial Reporting in Albania?. Academic Journal of Interdisciplinary Studies, 3(3), 371-377.

IASC Foundation Education. (2009). Training Material for the IFRS for NVMs. London: IASC Foundation Publications Department.

International Accounting Standards Board. (2009). Basis for Conclusions: IFRS for NVMs. (2009). [Booklet]. London: IASB.

International Accounting Standards Board. (2009). International Financial Reporting Standards (IFRS) for Small and Medium-sized Entities (NVMs) by International Accounting Standards Board (IASB). London: IASB.

International Accounting Standards Board. (2018). Basis for Conclusions: IFRS for NVMs.

Jarvis, R. (2003). Financial Reporting: IFRS and NVMs - A question of definition. Accountancy, 132(1323), 80.

Jarvis, R., \& Collis, J. (2003). IFRSs and Differential Reporting. British Accounting Association Annual Conference of the South Eastern Accounting Group, pp. 1-15.

Kılıç M., \& Uyar A. (2017). Adoption process of IFRS for SMEs in Turkey: Insights from academics and accountants. Accounting and Management Information Systems, 16(2), 313-339.

KKK-Standartet Kombëtare të Kontabilitetit- të përmisuara (në fuqi). Retrieved from http://www.kkk.gov.al/faqe.php?id=1\&12=136\&gj=sh

Lippitt, J., \& Oliver, B. (1983). Big GAAP, Little GAAP: Financial Reporting in the small business environment. Journal of Small Business Management.

Lungu, C., Caraiani, C., \& Dascalu, C. (2007). New Directions of Financial Reporting within Global Accounting Standards for Small and Medium-Sized Entities.

Mirza, A., Holt, G., \& Orrell, M. (2008). IFRS Practical Implementation Guide and Workbook (2nd ed.). New Jersey: John Wiley \& Sons, Inc.

Neag, R., Masca, E., \& Pascan, I. (2009). Actual Aspects Regarding The IFRS For NVM - Opinions, Debates and Future Developments. Annales Universitatis Apulensis Series Oeconomica, Faculty of Sciences, 1(11).

Pacter, P. Standards and NVMs: who, what, when and why?. Accounting \& business WCOA, special edition, 31-33.

Shortridge, R. T., \& Myring, M. (2004). Defining Principles-Based Accounting Standards. The CPA Journal Online.

Standardi Ndërkombëtar i Raportimit Financiar për Njësitë e Vogla dhe të Mesme SNRF për NJVM). (2009). f.9, 13-15. Retrieved from http://mf.rks-gov.net/desk/inc/media/0095870D-E242-4023-8C4C-33AF189441E0.pdf

Street, D., \& Jr. Needles, B. (2009). IFRS: Don't Get Caught Short. Journal of Accountancy, 207(5). 56-57.

Taylor, D. W. (2009). Costs-benefits of adoption of IFRSs in countries with different harmonization histories. Asian Review of Accounting, 17(1), 40-58.

William, M., \& Sinnett, M. G. (2006). What Do Users of Private Company Financial Statements Want?. Financial Executives Research Foundation.

\section{Copyrights}

Copyright for this article is retained by the author(s), with first publication rights granted to the journal.

This is an open-access article distributed under the terms and conditions of the Creative Commons Attribution license (http://creativecommons.org/licenses/by/4.0/). 